\title{
DEMOTIC RECEIPTS OF OIL
}

\section{By \\ Soheir Wahid El-Din}

Assoc. Prof. of Ancient Egyptian Language

Faculty of Arts- Mansoura University 


\section{DEMOTIC RECEIPTS OF OIL Soheir Wahid El-Din \\ Mansoura University}

\section{Abstract}

Nine more new demotic receipts from Elephantine at the Cairo Museum, deal with the oil payments. They are dated to the Ptolemaic period from year thirty of Ptolemy II Philadelphus to year twenty of Ptolemy III Euergetes.

Key words : Elephantine - Cairo Museum- Ptolemaic period - Ptolemy II Philadelphus - Ptolemy III Euergetes Demotic - Ostraca - Taxes - Receipts- Oil.

The nine demotic receipts from Elephantine at the Cairo Museum have been chosen among wider group of demotic ostraca which are preserved in a big box. They mainly deal with the oil payments and are dated to the Ptolemaic Period, from year thirty of Ptolemy II Philadelphus to year twenty of Ptolemy III Euergetes, according to the name of the payers and the scribes of the similar published receipts from the same period.

1 Cairo Museum : Inv.No. /TR. 18953/25-155,4 .

Dimension: $7 \mathrm{~cm} . \mathrm{X} 4.5 \mathrm{~cm}$., thickness $1 \mathrm{~cm}$.

Color: Reddish brown.

Date: 25 Dec. 256 to 23 Jan. 255 BC of Ptolemy II.

Description: The potsherd is scratched and palimpsest, most signs are very illegible.

Transliteration:

1 - in P3-tj - B3st.t s3 Ij - m - htp, (ht-kt) $1 / 4$

$2-(n) n h h(n)$ h3.t-sp 30 ibt-3 3h.t, sh

$3-P 3-h t r$ s3 Hr-t3j=f-nht.

\section{Translation:}

1 - Petebastis son of Imouthes, has paid 1/4 (silver-kite)

2 - (for) oil (of) year 30 Hathyr, signed

3 - Phatres son of Hartophnachthes.

\section{Notes:}

L.1- I could not find another similar instance for this payer's name Petebastis son of Imouthes.

- The kite sign is not attested before the fraction (1/4), because the fractions always refer to kite and it is not written with them.

L.2- The year number is written above the line to avoid a scratched part.
- This text is probably to be dated to the month Hathyr of year 30, running from 25 Dec. 256 to 23 Jan. 255 BC.

L.3- The scribe's name Phatres son of Hartophnachthes, is very faint. For the name of this scribe and others see, the comment in the table below.

2 Cairo Museum: Inv. No. /TR. 18953/25-1$55,4$.

Dimension: $8 \mathrm{~cm}$. X $6.5 \mathrm{~cm}$., thickness $1 \mathrm{~cm}$.

Color: Reddish brown.

Date: 12 June 254 BC of Ptolemy II.

Description: The potsherd is partly dark and palimpsest.

Transliteration:

1 - in Pa - Hnm s3 Hr-Pa -Is.t, db 2 .t $n$

2 - swn nhh (n) h3.t-sp 31 ibt-3 pr.t, sh

$3-P 3-h t r s 3 \mathrm{Hr}-t 3 j=f-n h t, n$ h3.t-sp $31 \mathrm{ibt}-$ 4 pr.t sw 20.

\section{Translation:}

1 - Pachnoumis son of Harpaesis, has paid 2 obols ( for)

2 - the price of oil (of) year 31 Phamenoth, signed

3 - Phatres son of Hartophnachthes, in year 31 Pharmouthi, day 20.

Notes:

L.1- Some traces of the previous text are visible above the first name Pachnoumis.

- I could not find another similar instance for this payer's name Pachnoumis son of Harpaesis.

L-2-The sign $(s \underline{h})$ overlaps the figure twenty of the date at the end of the next line.

L. 3 - The date of year 31 Pharmouthi, day 20 corresponds to: 12 June 254BC.

3 Cairo Museum : Inv. No. /TR. 18953/25$1-55,4$.

Dimension: $16 \mathrm{~cm} . \mathrm{X} 11 \mathrm{~cm}$. , thickness 1 $\mathrm{cm}$. 
Color: Reddish brown.

Date: 10 June 250 BC of Ptolemy II.

Description: The potsherd is palimpsest.

\section{Transliteration:}

$1-$ in $\mathrm{Hr}-\mathrm{Pa}-I$ s.t $s 3 \mathrm{P} 3-\mathrm{m}_{3} \mathrm{j}$,

$2-h t(-k t) 1 / 4$ swn p3 nhhh, $r-s ̌ p=f(n)$ ḩ 3.t-sp 35

3 - ibt-3 pr.t, sh P3-ḥtr s3 Hr-t3j=f-nht, $r-$ hrw

4 - Pa - $\underline{H} n m$ (s3) Pa -Hr, n ḩ3.t-sp 35 ibt-4 pr.t sw 19.

\section{Translation:}

1 - Harpaesis son of Pemaus, has paid

$2-1 / 4$ silver (-kite) price for the oil which he has received (of) year 35

3 - Phamenoth, signed Phatres son of Hartophnachthes, on behalf of

4 - Pachnoumis son of Pauris, in year 35 Pharmouthi, day 19.

\section{Notes:}

L. 1- I could not find another similar instance for this payer's name Harpaesis son of Pemaus.

- The patronymic Pemaus is attest in the Demotisches Namenbuch. ${ }^{2}$

L .2 - The formula of $(r-\breve{s} p=f)$ is attested with another receipts of the same tax. ${ }^{3}$

$\mathrm{L}$ - 4- The date of year 35, pharmouthi, day 19 corresponds to: 10 June $250 \mathrm{BC}$.

4 Cairo Museum: Inv. No. /TR. 18953/25$1-55,4$.

Dimension: $6 \mathrm{~cm}$. X $3 \mathrm{~cm}$., thickness $1.5 \mathrm{~cm}$.

Color: Reddish brown.

Date: 19 Jan. to17Feb. 236 BC of Ptolemy III.

Description: The potsherd is palimpsest. Some signs of the previous Greek text are visible at the bottom.

\section{Transliteration:}

1 - in Br s3 hrj-inp (ht-)kt 1/3 1/6,

2 - n p3 nhh n h3.t-sp 11 ibt-4 3h.t sh P3-htr s) $\mathrm{Hr}--t 3 j=f n h t$

3 - sh Imn- htp s3 Pa- wn

\section{Translation:}

1 - Belles son of Herianup, has paid 1/3 1/6 (silver-) kite

2 - for the oil of year 11 choiach, signed by Phatres son of Har-

- tophnachthes
3- signed Amenothes son of Pagonis.

Notes

L. 1- The payer Belles son of Herianup is known from other receipt. ${ }^{4}$

L.2- The sign ( $p 3)$ is illegible.

- The scribe's name Phatres son of Hartophnachthes, is very faint. The name is completed by adding the later part between line two and line three.

- The date of year 11 choiach is running from 19 Jan. to 17 Feb. 236 BC.

5 Cairo Museum: Inv. No. /TR. 18953/25$1-55,4$.

Dimension: $9 \mathrm{~cm}$. X $6.5 \mathrm{~cm}$., thickness $1 \mathrm{~cm}$.

Color: Reddish brown.

Date: 19 Nov.to18 Dec. 232 BC of Ptolemy III.

Description: The text's writing is complete. Some signs at the third line are very illegible.

\section{Transliteration:}

1 - in Pa - Hnm s3 P3-hb hnc

$2-s t m-n=j-\underline{H} n m p 3 j=f \breve{s} r h t(-k t) 1 / 3 d b^{c} 1 / 2$ (n) $n h h$

3 - h3.t-sp 16.t ibt-2 3h.t sh P3-htr.

\section{Translation:}

1 - Pachnoumis son of Phibis, with

2 -Stamnaichnoumis his son, 1/3 (silver-) kite $1 / 2$ obol (for) oil

3 - of year 16.t paophi, signed Phatres.

\section{Notes}

L.1- The payer Pachnoumis son of Phibis, is recurred in another eleven receipts. ${ }^{5}$

L.2- The son of the payer Stamnaichnoumis is known from other receipts. ${ }^{6}$

$\mathrm{L}$ - The year number is very illegible, but the reading is surely.

- The date of year 16 Paophi is running from 19 Nov. to 18 Dec. 232 BC.

Cairo Museum: Inv. No. /TR. 18953/25-1$55,4.6$

Dimension: $10.5 \mathrm{~cm} . \mathrm{X} 9.5 \mathrm{~cm}$. , thickness $1 \mathrm{~cm}$.

Color: Reddish yellow.

Date: 18 Jan. to17 Fab. 230 BC of Ptolemy III.

Description: The potsherd is complete and palimpsest. 


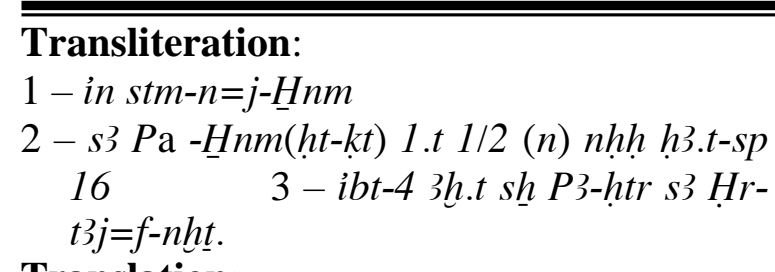

\section{Translation:}

1 - stamnaichnoumis

2 - son of Pachnoumis, has paid 1.t 1/2 (silver-kite) (for) oil (of) year16

3 - choiach, signed Phatres son of Hartophnachthes.

\section{Notes}

L.1- The payer Stamnaichnoumis son of Pachnoumis, is mentioned with his father at the previous text, line two.

L. 3 - The date of year 16 choiach is running from 18 Jan. to $17 \mathrm{Fab} .230$ BC.

Cairo Museum: Inv. No. /TR. 18953/251-55,4. 7

Dimension: $5 \mathrm{~cm} . X 3.5 \mathrm{~cm}$. thickness $.5 \mathrm{~cm}$.

Color: Reddish brown.

Date: 17 May to 15 June. 229 BC of Ptolemy III.

Description: The text's writing is complete.

\section{Transliteration}

1 - in Ns - p3-mty s3

2 - Ij-m- htp ht (-kt) $1 / 4$ (n) nḥh (n) ḩ3.t-sp 18

3 - ibt-4 pr.t sh P3-ḥtr.

\section{Translation:}

1 - Espemetis son of

2 - Imouthes, has paid 1/4 silver (-kite) (for) oil (of) year 18

3 - pharmouthi, signed Phatres.

\section{Notes}

L.1- The payer Espemetis son of Inouthes, is known from other receipts. ${ }^{7}$

L.2- the date year 18 pharmouthi of Ptolemy III is running from 17 May to 15 June 229 BC.

: Inv. No. /TR. 18953/25-1-55,4. Cairo Museum 8

Dimension: $7.5 \mathrm{~cm}$. X $5.5 \mathrm{~cm}$, thickness $.5 \mathrm{~cm}$.

Color: Reddish brown.

Date: 15 July to 13 Aug. 227 BC of Ptolemy III.

Description: The text's writing is complete.

\section{Transliteration}

1 - in P3-wr-i3bt s3 Pa-snj (ht-kt) 1.t 1/2 (n) $n h h$

2 - (n) ḩ.t-sp 20.t ibt-2 šmw sh P3-tj-Imn$n s w-t 3 . w j$ s3 Pa $-t 3 . w j$

Translation:

1 - Pwereiebt son of Pasenis, has paid 1.t $1 / 2$ (silver-kite) (for) oil

2 - (of) year 20.t payni, signed Petemestous son of Patous.

\section{Notes}

L.2- The payer Pwereiebt son of Pasenis, is recurred in other receipt. ${ }^{8}$

L.3- The date of year 20.t payni is running from 15 July to 13 Aug. 227 BC.

Cairo Museum : Inv. No. /TR. 18953/25-155,4. 9

Dimension: $7.5 \mathrm{~cm} . \quad X \quad 5 \mathrm{~cm} .$, thickness $.5 \mathrm{zcm}$.

Color: Reddish brown.

Date : 15 July to 13 Aug. 227 BC.

Description : The potsherd is palimpsest.

\section{Transliteration}

1 - in Pa-snj s3 Ns -p3-mty, (ht-kt)1/4

2 - (n) nhhh (n) ḩ3.t-sp 20.t ibt-2 šmw sh P3tj-Imn-nsw-t3.w

$3-s 3 P$ a $-t 3 . w j$.

Translation:

1 - Pasenis son of Espemetis, has paid 1/4 (silver-kite)

2 - (for) oil (of) year 20.t payni, signed Petemestous

3 - son of Patous.

\section{Notes}

L.1- The payer Pasenis son of Espemetis, is known from other receipts. ${ }^{9}$

L.3- The date of year 20.t payni is running from July to 13 Aug. 227 BC.

\section{Comment:}

The oil was a state monopoly. ${ }^{10}$ The state limited the quantity of oil producing plants and prohibited imports of oil into the countryside, ensuring that all the limited quantities of oil produced in each district would be sold at fixed prices included a profit. The receipts of oil were monthly payments for uncertain quantities of oil received. $^{11}$ 
The following table sums up the payment of the oil, the payment dated through reigns of Ptolemy II Philadelphus and Ptolemy III

Euergetes (the equivalent of the date depends on Skeet), ${ }^{12}$ the name of the payers and the name of the scribes:

\begin{tabular}{|c|c|c|c|c|c|c|c|c|}
\hline No. & payers & $\begin{array}{l}\text { Paymen } \\
\text { t }\end{array}$ & Month & $\begin{array}{l}\text { Signed } \\
\text { in }\end{array}$ & year & Scribes & Scribe on behalf of & $\begin{array}{l}\text { Ptolem } \\
\text { y }\end{array}$ \\
\hline 1 & P3-tj-B3st.t s了 Ij-m-htp & $\begin{array}{l}(h t-k t \quad) \\
1 / 4\end{array}$ & ibt-3 3h.t & - & 30 & $\begin{array}{l}P 3-h t r s 3 \\
H r-t 3 j=f- \\
n h t \underline{t}\end{array}$ & - & II \\
\hline 2 & $\begin{array}{l}P \mathrm{~Pa}-\mathrm{Hnm} \text { s3 } \mathrm{Hr}-\mathrm{Pa}- \\
\text { Is.t }\end{array}$ & $\underline{d} b^{\ulcorner} 2 . t$ & ibt-3 pr.t & $\begin{array}{l}\text { ibt-4pr.t } \\
\text { sw } 20\end{array}$ & 31 & $\begin{array}{l}P 3-h t r \quad s 3 \\
H r-t 3 j=f- \\
n h \underline{t} \underline{ }\end{array}$ & - & II \\
\hline 3 & Hr-p3-Is.t s3 P3-m3j & $\begin{array}{ll}h t & (-k t) \\
l / 4\end{array}$ & $i b t-3$ pr.t & $\begin{array}{l}\text { ibt-4pr.t } \\
\text { sw19 }\end{array}$ & 35 & $\begin{array}{l}P 3-h t r s 3 \\
H r-t 3 j=f- \\
n h t\end{array}$ & $P \mathrm{a}-\underline{H} n m \mathrm{~s}_{3} \mathrm{~Pa}-\mathrm{Hr}$ & II \\
\hline 4 & Br s3 hrj-inp & $\begin{array}{l}(h t-) k t \\
I / 3, i / 6\end{array}$ & ibt-43h.t & - & 11 & $\begin{array}{l}\text { Imn-htp } \\
\text { s3 Pa -wn } \\
P 3-h t r \quad \text { s } \\
H r-t 3 j=f- \\
n h t\end{array}$ & - & III \\
\hline 5 & $\begin{array}{l}P \text { Pa } \quad-H n m \quad s 3 \quad P 3-h b \\
s r=f \\
s t m-n=j-H n m\end{array}$ & $\begin{array}{ll}h t & (-k t \\
j l 13 & d b^{c} \\
1 / 2 & \end{array}$ & $i b t-23 h t$ & - & 16 & P3-htr & - & III \\
\hline 6 & $\begin{array}{l}\text { stm-n=j-Hnms3 Pa - } \\
\text { Hnm }\end{array}$ & $\begin{array}{l}(h t-k t) l . t \\
1 / 2\end{array}$ & $i b t-43 h t$ & - & 16 & $\begin{array}{l}P 3-h t r s 3 \\
H r-t 3 j=f- \\
n h t\end{array}$ & - & III \\
\hline 7 & $N s-p 3-m t j$ s3 $i j-m-h t p$ & $\begin{array}{l}h t-(k t \\
) 1 / 4\end{array}$ & Ibt-4 pr.t & - & 18 & $P 3-h t r$ & - & III \\
\hline 8 & $P$ P-wr-ỉbt s\} $P a-s n j$ & $\begin{array}{l}(h t-k t) 1 . t \\
1 / 2\end{array}$ & $\begin{array}{l}i b t-2 \\
\check{s} m w\end{array}$ & - & $20 . \mathrm{t}$ & $\begin{array}{l}P \text { P-tj-Imn- } \\
n s w-t 3 . w j \\
\text { s? Pa-t3.wj }\end{array}$ & - & III \\
\hline 9 & $N s-p 3-m t j P a-s$ & $\begin{array}{l}(h t-k t) \\
1 / 4\end{array}$ & $\begin{array}{l}i b t-2 \\
s m w\end{array}$ & - & $20 . \mathrm{t}$ & $\begin{array}{l}P 3-t j-I m n- \\
n s w-t 3 . w j \\
\text { s3 Pa-t3.wj }\end{array}$ & - & III \\
\hline
\end{tabular}

The oil payments are monthly payment, paid at any month during the whole year. They are sometime paid for two consecutive months of the same season. ${ }^{13}$ The mention of the payment day is often omitted on the oil receipts, but it must be written when it paid during a current month about a previous month (nos.2-3).

The variations payment of oil receipts must be defined according to specified quantities of oil received which are not included on the receipts. We represent an instance for payments of our payer Pachnoumis son of Phibis (no.5), dated for Ptolemy III Euergetes:

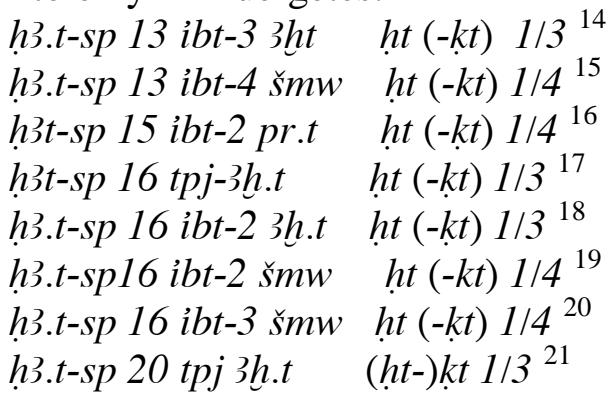

$$
\begin{array}{llll}
\ldots & & t p j-p r . t & h t(-k t) 1 / 4^{22} \\
\ldots & \ldots & & h t(-k t) 1 / 4
\end{array}
$$

During eight years (from year 13 to year 20), Pachnoumis son of Phibis, has paid his monthly payments at any month during the year. The payments (1/3 and 1/4 silver-kite) all those years means that he has received a fixed quantities and the price changed according to turn over in the trade.

As for the scribes who are mentioned here and signed these receipts, they are: Imn-htp s3 Pa- wn

He signed one receipt (no.4) in this study. The scribe Phtres son of Hartophnachthes associated with him. This scribe is mentioned twice in two published receipts of the same oil payments and one of them for year eleven of Ptolemy III Euergetes as it is in our receipt. ${ }^{24}$ Devauchelle read the scribe's name as $\mathrm{CHr}$ $n f r$ s3 P3-t3.wj), but the demotic signs seem clearly for the reading as (Imn-htp s3 Pa$w n)^{25}$

P3-htr s3 Hr-t3j=f-nht ...P3-htr 
This scribe is known from a long list of oil and salt payments running from year thirty of Ptolemy II Philadelphus until year twenty five of Ptolemy III Euergetes. Seven receipts of oil payments will be added here for the previous long list at the same period, other scribes associated with him. ${ }^{26}$ P3-tj-Imn-nsw-t3.wj s3 Pa -t3.wj

He signed eleven receipts of oil and compulsory labor payments, dated from year thirteen to year twenty three of Ptolemy III Euergetes; two of them are attested in this study. ${ }^{27}$ Wångstedt attributed our scribe to Thebes but he is well known in Elephantine. 28

\section{P3-Hnm s3 P3- $\mathrm{Hr}$}

This name is recurred as a scribe in ten receipts, dated from year thirty five of Ptolemy II Philadelphus to year thirteen of Ptolemy III Euergetes. All receipts deal with oil, sheep and yoke payments, all of them are signed by other scribes on behalf of our scribe Pachnoumis son of Pauris. ${ }^{29}$

\section{Endnotes:}

1- B. P. Muhs, Tax Receipts, Taxpayers, And Taxes In Early Ptolemaic Thebes. OIP 126 (Chicago, Illinois, 2005), 77 ( note 546).

2- E. Lüddeckens, Demotisches Namenbuch. Band 1/3 (Wiesbaden, 1983), 186.

3- D. Devauchelle, Ostraca Démotiques du Musée du Louvre. 2 vols. (Le Caire, 1983),73,78,81,84-85 (nos.,8,34,41,276,284).

4 - S.P. Vleeming, Ostraka Varia: Tax Receipts and Legal Documents on Demotic, Greek, and Greek-Demotic Ostraka, Chiefly of The Early Ptolemaic Period, From Various Collections. P.L.Bat. 26 (Leiden, New York, Köln, 1994), 27 (no.11).

5 - G. Mattha, Demotic Ostraca from the Collection at Oxford, Paris, Berlin, Vienna and Cairo, Publications de la Société Fouad 1 de Papyrologie Textes et Documents VI.( Le Caire, 1945),119 (no.108); O. El-Aguizy 'Some demotic Ostraca in the Cairo Museum', EVO17
(1994), 132(no. O.Cairo 12465,2);

Devauchelle,

Ostraca

Démotiques,71,74, 76-78,92,86,198,87( nos. 4,11,23,27,33,290,302,899,944).

6 - Devauchelle, Ostraca Démotiques, 72,79,82,85-6 (nos.5,36,43,301).

Devauchelle, Ostraca Démotiques, 159,91, 167 (nos.109,267,293). 7 -

8 - Mattha, Demotic Ostraca, 118 (106).

9 - Devauchelle, Ostraca Démotiques, 50 (no.261); G.R. Hughes, Catalog Of Demotic Texts In The Brooklyn Museum. OIP 29 (Chicago, Illinois, 2005), 61 (no. 155).

10 - S. L. Wallace, Taxation in Egypt from Augustus to Diocletian. (Princeton, London, 1938),185; Cl. Preaux, L'Economie royale des Iagides. (Bruxelles, 1939), 93.

11 - Muhs, Tax Receipts, Taxpayers, And Taxes, 73.

12 - Th. Skeat, C. The Reigns of The Ptolemies. MBPF 39 (München, 1954).

13-S.V.Wångstedt,' Demotische Quittungen über Ölsteuer',Or.Suec. 29 (1980), 22 (no.BM 43584); Vleeming, Ostraka Varia, 26 (no. 10).

14- Devauchelle, Ostraca Démotiques ,86 (no.302), the editor read 1/4 instead of $1 / 3$.

15 - Devauchelle, Ostraca Démotiques ,87 (no.944).

16 - Devauchelle, Ostraca Démotiques ,74 (no.11).

17 - Devauchelle, Ostraca Démotiques ,77 (no.27).

18 - This study, (no. 5).

19 - Mattha, Demotic Ostraca, 119 (108).

20 - Devauchelle, Ostraca Démotiques ,71 (no.4).

21 - El-Aguizy, EVO 17 (1993),132 (no. O. Cairo12456, 2).

22 - Devauchelle, Ostraca Démotiques, 76 (no. 23).

23 - Devauchelle, Ostraca Démotiques, 78 (no. 33).

24 - Devauchelle, Ostraca Démotiques, 72, 76 (nos. 5, 23). 
25-Lüddeckens, Demotisches Namenbuch, Band 1/2, 67, Band 1/5, 358.

26 -Devauchelle, Ostraca Démotiques, 1416; Vleeming, Ostraka Varia, 26-27, 42 (nos. 10-11, 15); S. Wahid El-Din, Some Demotic Ostraca from Cairo Museum. (M. A. Degree., University of Zagazig, 1997), 7-8 (nos.5, 11, 13); Hughes, Catalog Of Demotic Texts In The Brooklyn Museum, 25 (no. 74).

27 -Wångstedt, Or.Suec. 29, 22(no.BM 43584); Devauchelle, Ostraca Démotiques, 74, 81, 32, 87 (nos. 11, 40,
56, 944); El-Aguizy, EVO 17 (1993), 132(nos. O. Cairo 12456,2- 12456,3); Wahid El-Din, 'Demotic Receipts of Compulsory Labor Tax', ASAE 90 (2017), (no.16).

28 -Muhs, Tax Receipts, Taxpayers, And Taxes, 79.

29 - Devauchelle, Ostraca Démotiques, 46, 49, 181, 51, 186, 51- 53 ( nos.82, 89, $160, \quad 285, \quad 289, \quad 891, \quad 902, \quad 1422)$; Vleeming, Ostraka Varia, 7, 60 (nos.1, 26). 
PL.1
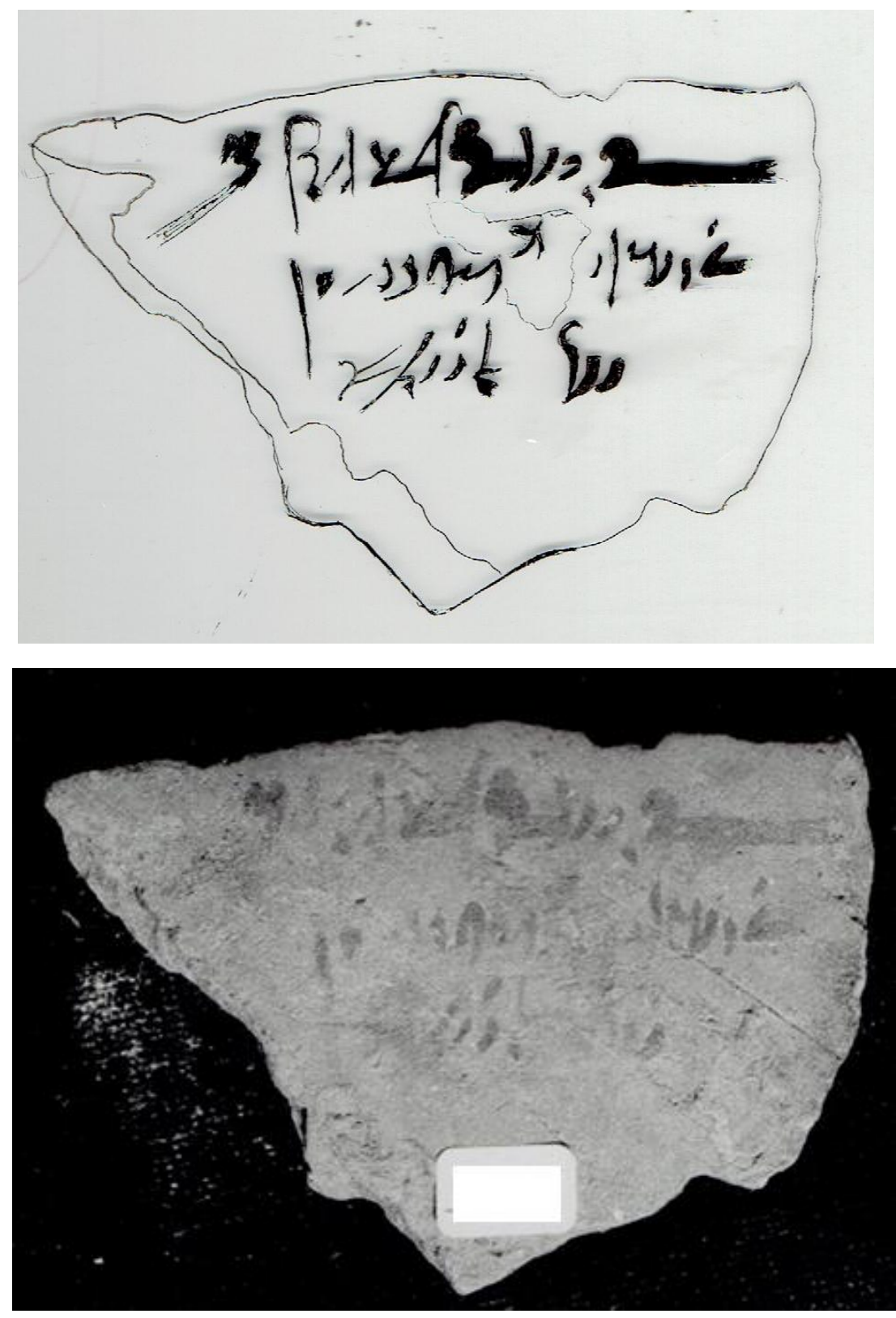

1- Cairo Museum : Inv.No. /TR. 18953/25-1-55,4 
PL.2
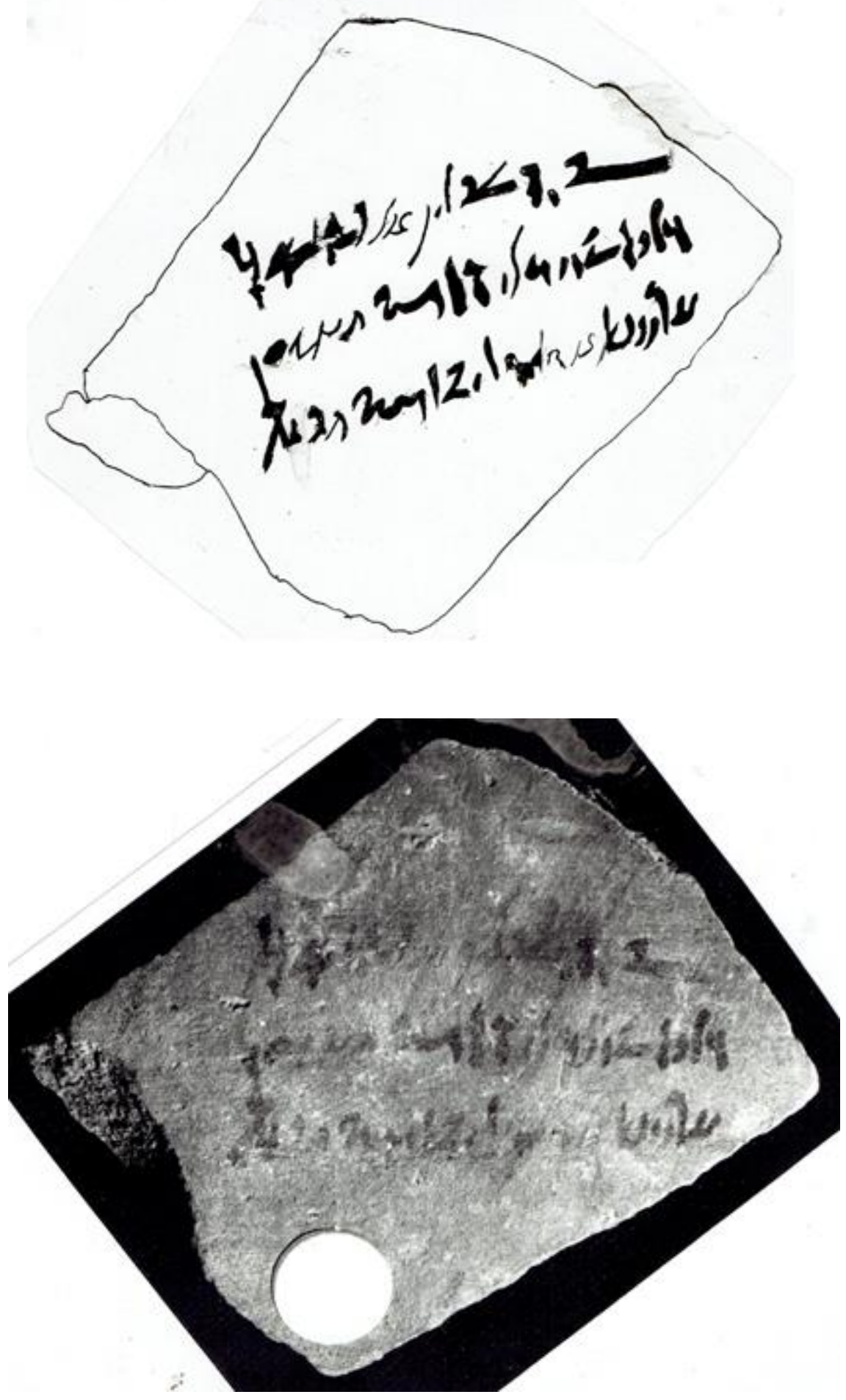

2- Cairo Museum : Inv.No. /TR. 18953/25-1-55,4 


\section{PL.3}
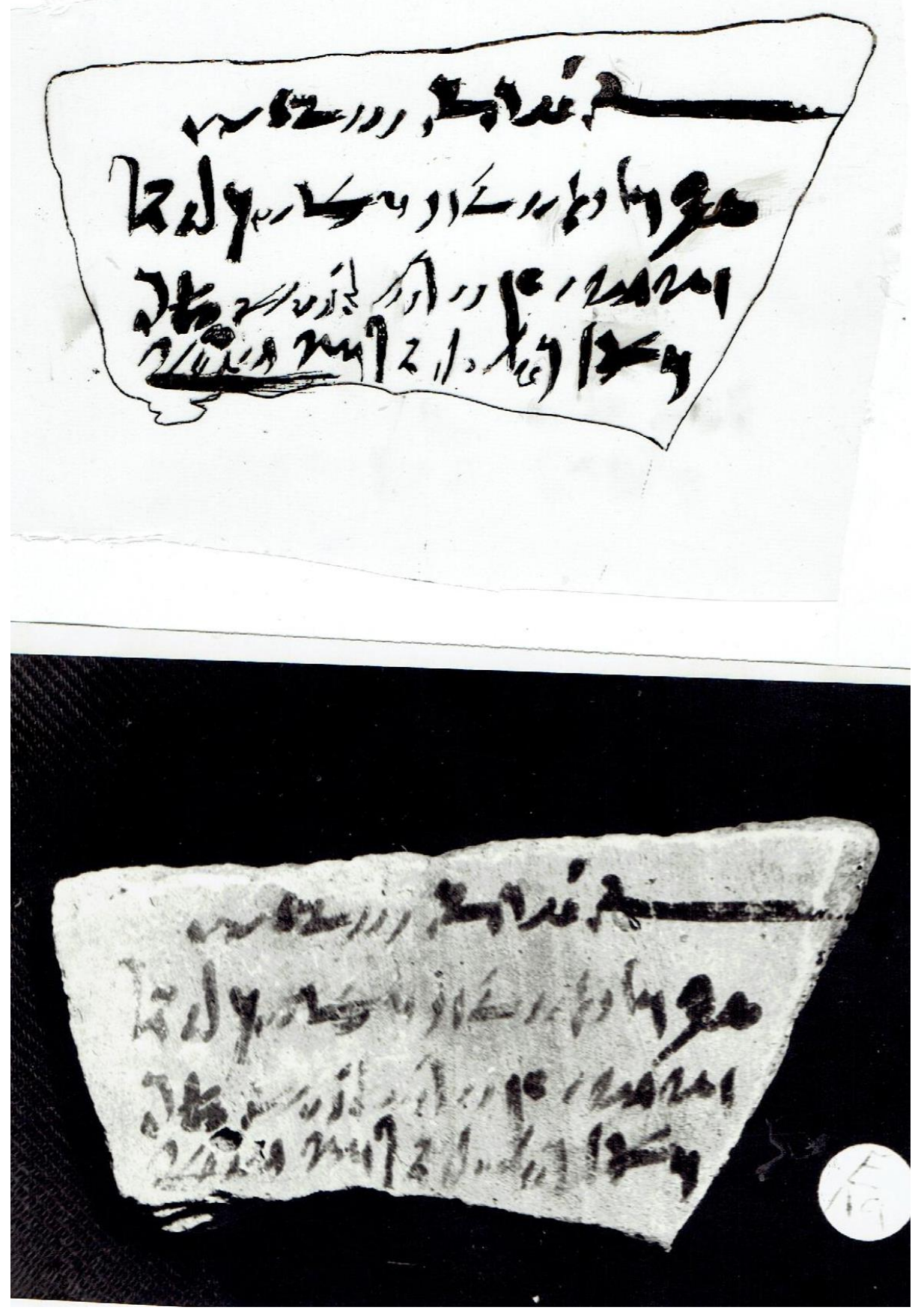

3- Cairo Museum : Inv.No. /TR. 18953/25-1-55,4 


\section{PL.4}
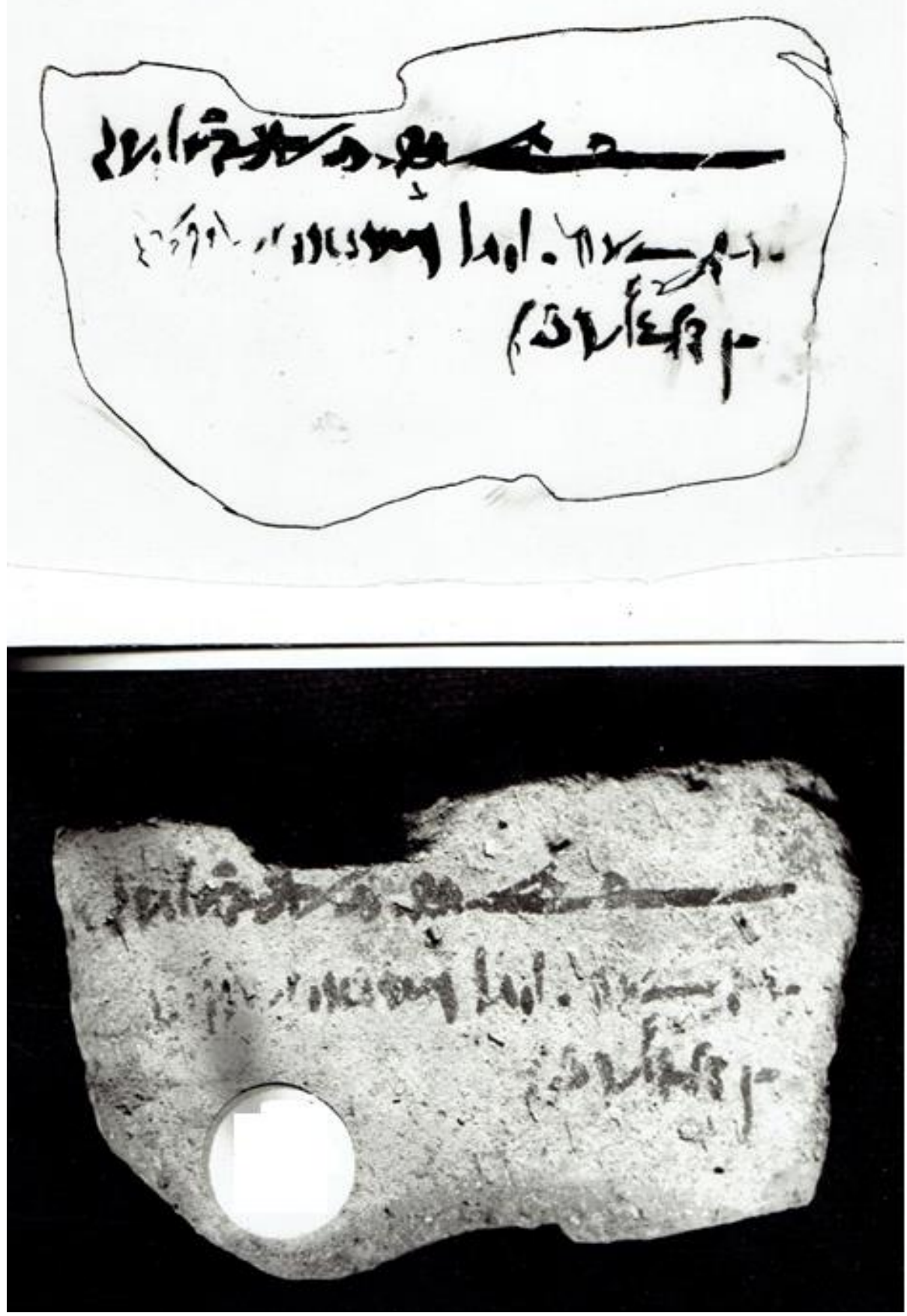

4- Cairo Museum : Inv.No. /TR. 18953/25-1-55,4 


\section{PL.5}
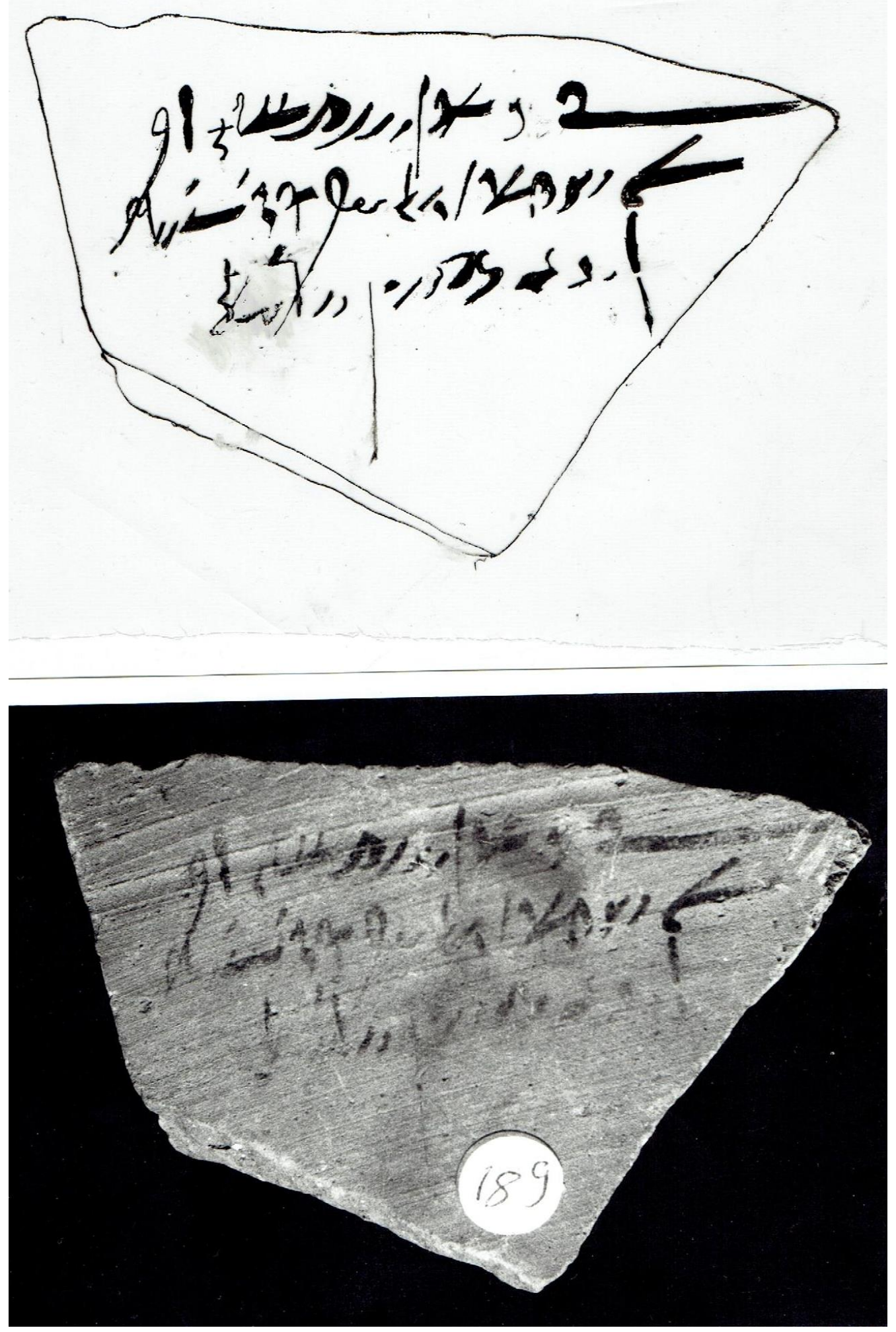

5- Cairo Museum : Inv.No. /TR. 18953/25-1-55,4 
PL.6
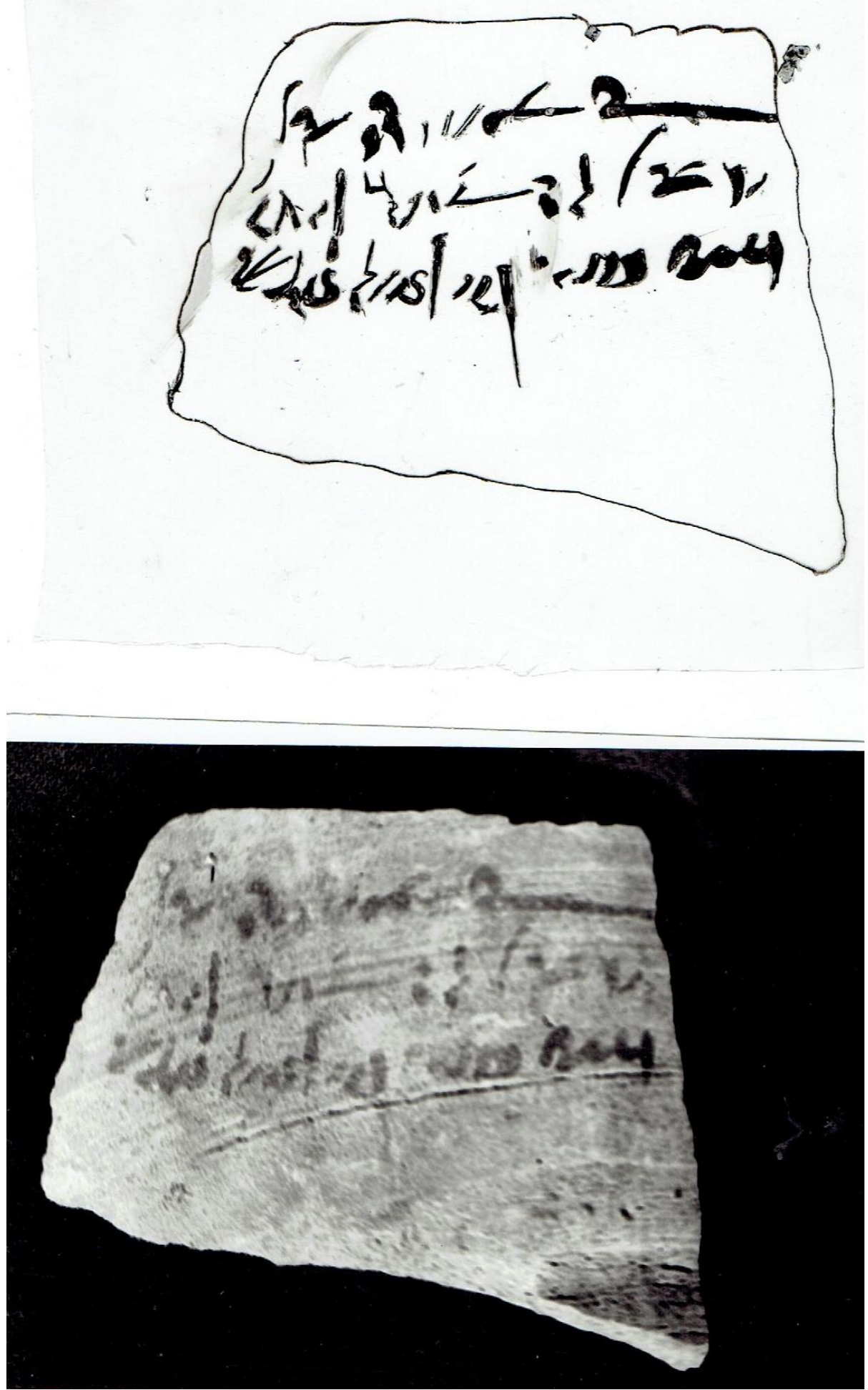

6- Cairo Museum : Inv.No. /TR. 18953/25-1-55,4 


\section{PL.7}
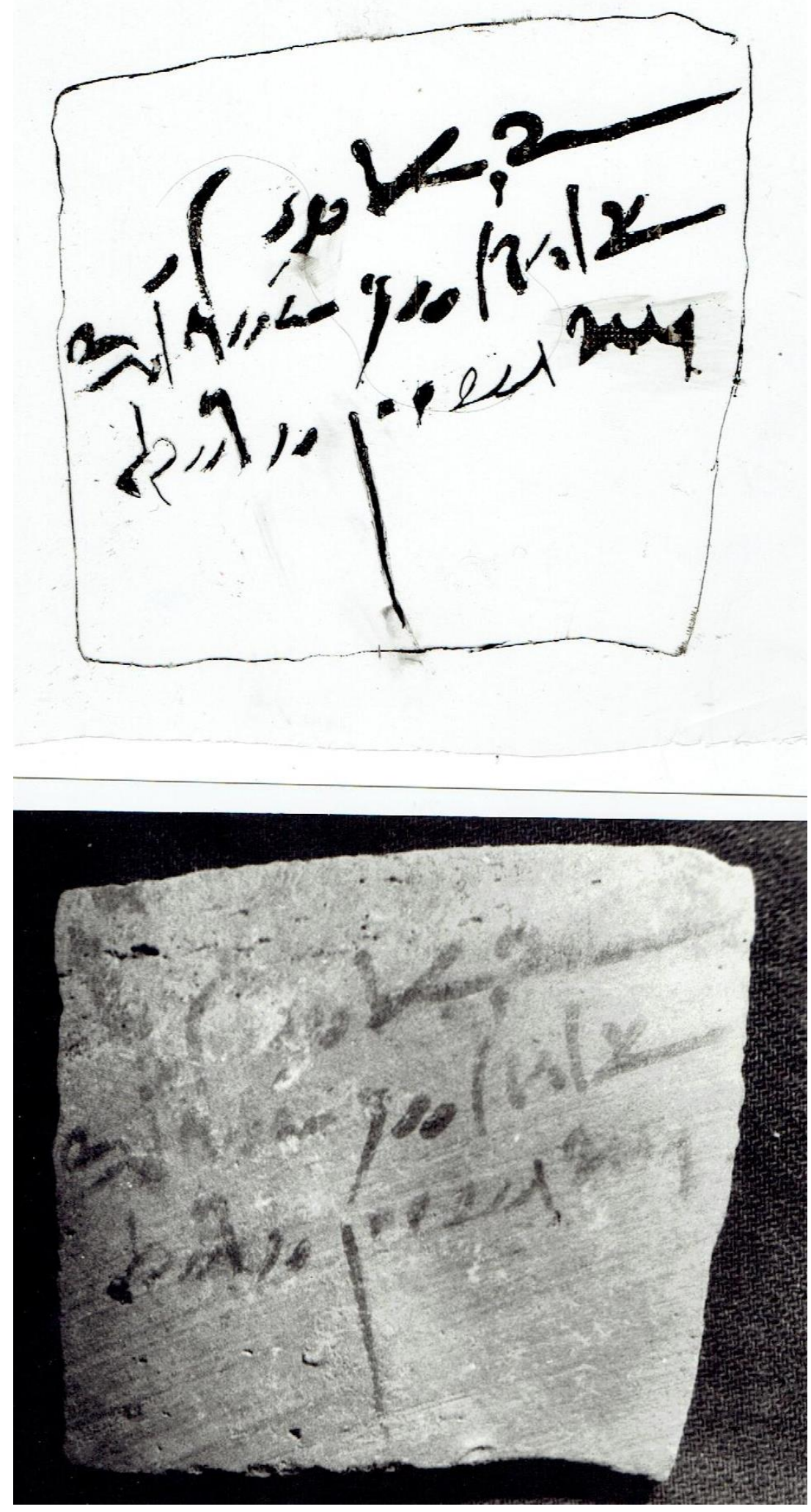

7- Cairo Museum : Inv.No. /TR. 18953/25-1-55,4 


\section{PL.8}
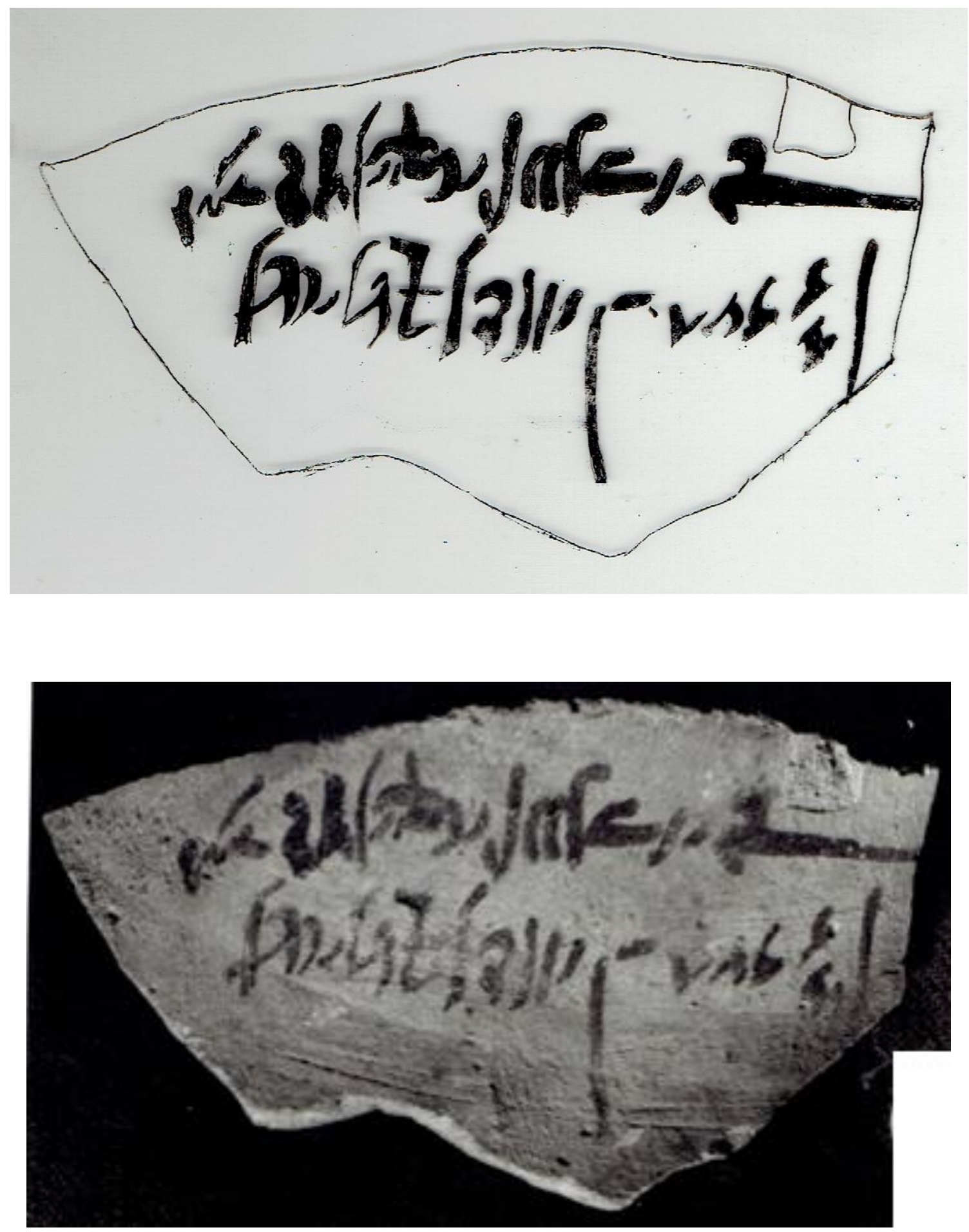

8- Cairo Museum : Inv.No. /TR. 18953/25-1-55,4 


\section{PL.9}
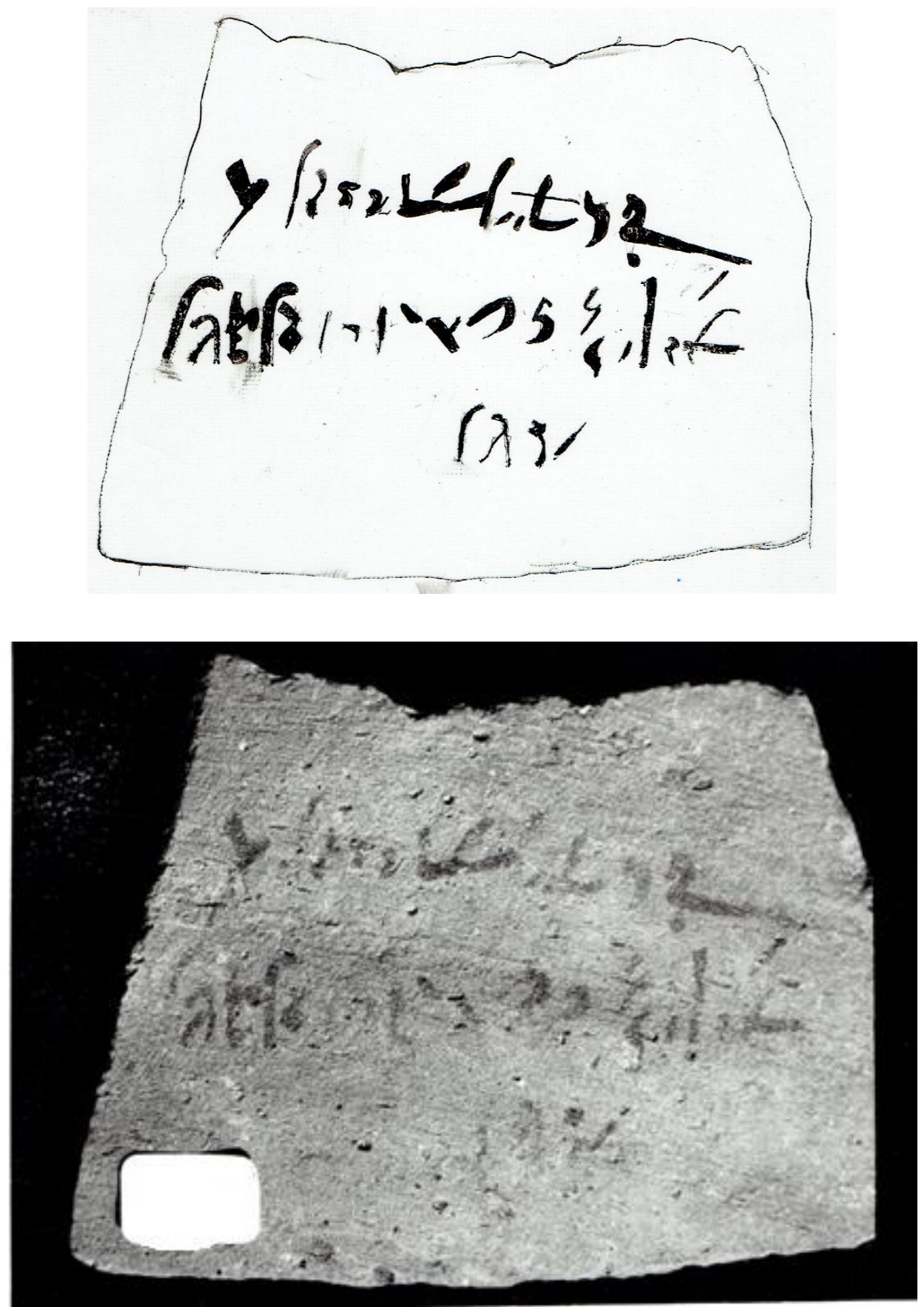

9- Cairo Museum : Inv.No. /TR. 18953/25-1-55,4 